\title{
VIBRIOSIS IN FARM REARED WHITE SHRIMP, LITOPENAEUS VANNAMEI IN ANDHRA PRADESH-NATURAL OCCURRENCE AND ARTIFICIAL CHALLENGE
}

\author{
S.A. Mastan ${ }^{1}$ and S.K. Aktharunnisa Begum ${ }^{2 *}$ \\ ${ }^{1}$ Karyotica Biologicals Pvt. Ltd., Madhapur, Hyderabad-500 081, India \\ ${ }^{2}$ Department of Education (Biological Sciences), St. Joseph College of Education for Women, Guntur-534 001, A.P., India \\ Corresponding author's email: shaikmastan2000@yahoo.com / samastan386@gmail.com
}

\begin{abstract}
In the present study, a total of five species of Vibrio bacteria were isolated from diseased shrimp, Litopenaeus vannamei, collected from commercial shrimp cultured ponds of Eethamukkala, Chinaganjam and Pedaganjam areas, Prakasam district, Andhra Pradesh. The isolated bacterial species were identified as Vibrio parahaemolyticus, Vibrio harveyi, Vibrio alginolyticus, Vibrio mimicus and Vibrio vulnificus. The symptoms shown by diseased shrimps include loss of appetite, red coloration of the body and pleopods, gills often appear red to brown in colour, reduced feeding, empty gut and general septicemia. In diseased shrimp, hepatopancrocytes may appear poorly vacuolated, indicating low lipid and glycogen reserve. In affected shrimps, localized lesions were also observed in the cuticle. Experimental infection trials reveals that $V$. parahaemolyticus is highly pathogenic to $L$. vannamei while $V$. harveyi found to be moderate pathogenic to challenged shrimp and remaining three bacterial species namely V.alginolyticus, V.mimicus and V.vulnificus were less pathogenic in nature.
\end{abstract}

Keywords: Shrimp; infection; vibriosis; bacteria

\section{Introduction}

The intensification of the shrimp culture and the transfer of aquatic organisms worldwide have been accompanied over the last twenty years by an increased incidence of microbial infectious pathogens. In this regard, bacterial diseases due to Vibrio species are often associated with low survival rates in hatchery or grow out conditions (Denis Saulnier et al., 2000). Larval mortalities associated with the presence of $V$. harveyi have been reported in $P$. monodon and $P$. vannamei in Indonesia (Sunaryanto and Mariam, 1986), Thailand (Jiravanichpaisal et al., 1994), India (Karunasagar et al., 1994), Philippines (Baticados et al., 1990; Lavilla-Pitogo et al., 1990), Australia (Pizzutto and Hirst, 1995), Taiwan (Song and Lee, 1993; Liu et al., 1996) and Ecuador (Robertson et al., 1998). Disease outbreaks attributed to other Vibrio species such as $V$. alginolyticus, V. damsela, $V$. parahaemolyticus, $V$. vulnificus and $V$. penaeicida have been observed in nursery or grow out ponds of $P$. vannamei, $P$. monodon, $P$. japonicus and P. stylirostris in Ecuador (Lightner, 1992) Malaysia (Anderson et al., 1988) Taiwan (Song et al., 1993; Lee et al., 1996), Philippines (AlapideTendencia and Dureza, 1997), Japan (de la Pena et al., 1993) and New Caledonia (Costa et al., 1998).

Vibriosis is a bacterial infection responsible for mortality of commercial shrimp culture system worldwide (Lightner and Lewis, 1975; Overstreet, 1978; Sidermann, 1990; Lightner et al., 1992; Lavilla-Pitogo et al., 1996; Lavilla-Pitogo et al., 1998; Chen et al., 2000). Vibrio species are widely distributed in aquaculture facilitates throughout the world. Vibrio-related infections also occur in hatcheries, but epizootics also commonly occur in pond reared shrimp species. This disease is caused by gram-negative bacteria of the family Vibrionaceae. Outbreaks may occur when environmental factors trigger the rapid multiplication of bacteria already tolerated at low levels within shrimp body (Sizemore and Davis, 1985) or by bacterial penetration of host barriers. Vibrio spp., are among the chitinoclastic bacteria associated with shell disease (Cook and Lofton 1973) and may enter through wounds in the exoskeleton or pores (Jiravanichpaisal and Miyazaki, 1994). The gills may appear susceptible to bacterial penetration because they are covered by a thin exoskeleton (Taylor and Taylor, 1992), but their surfaces are cleaned by the seto-branchs (Bauer, 1998). The mid gut, composed of the digestive gland (DG) and the mid gut trunk (MGT, often referred to as the intestine, (Lovett and Felder, 1990), is not lined by an exoskeleton and therefore seems to be a likely site for penetration of pathogens carried in the water, food and sediment (Ruby et al., 1980; Denis Saulnier et al., 2000 and Jayasree et al., 2006). The present paper communicates incidences of Vibriosis in farm reared shrimp, L. vannamei 
in Andhra Pradesh-Natural occurrence and artificial challenges.

\section{Materials and Methods}

\section{Collection of Diseased Shrimp Samples}

In the present study, a total of 250 diseased alive shrimp (weight between 16-18 gm) samples were collected from commercial cultured ponds of Eethamukkala, Chinaganjam and Pedaganjam areas of Prakasam district, Andhra Pradesh. The diseased shrimp samples were brought to laboratory under sterilized conditions. Affected shrimps were observed for gross symptoms by keeping them in glass aquaria. Morphological and behavioral symptoms of affected shrimps were recorded. For the isolation of bacteria from affected shrimps, standard methods described by Lightner (1995) were fallowed. Haemolymph drawn from affected shrimp and plated onto Trytone Soy Agar (TSA) and Thiosulphate Citrate Bile Sucrose (TCBS). Samples were taken aseptically from different tissues such as hepatopancreas, intestine and haemolymph and inoculated onto the surface of TSA and TCBS agar plates. Inoculated plates were incubated at $30 \pm 2^{\circ} \mathrm{C}$ for $24 \mathrm{~h}$. Bacterial colonies were observed in incubated plated from 24 to $96 \mathrm{~h}$. The purification of bacteria was done by subsequent culturing of bacterial cultures. Identification and characterization of bacteria was done on the basis of their biochemical tests as per the methods of Buchanan and Gibbons (1974). Biochemical tests such as Gram's staining, Catalase, Oxidase, MR-VP test, Urase, Oxidative/Fermentative test, and Citrate utilization tests were carried out in the laboratory condition.

\section{Artificial Infection Trials}

In order to confirm the pathogenicity of isolated bacterial species from diseased shrimp and to verify the Koch's Postulates, pathogenicity experiments have been conducted in the laboratory condition. For this purpose a total of 500 alive healthy, diseased free shrimp were procured from local shrimp farm (Average weigh 8-10 gm and Length 5$8 \mathrm{~cm}$ ) used in this study and were acclimatized in the laboratory condition for one week. In each group 20 animal were used and kept in glass aquaria and filled with 20 litre of freshwater. The isolated bacterial species were cultured in TS broth and purified. The purified cultures were used to prepare the bacterial cell suspension in $0.85 \%$ saline solution to get appropriate cell number in the suspension. Then the suspension contains cell number from $10^{4}$ $10^{6} \mathrm{cfu} / \mathrm{shrimp}$ were injected intramuscularly (IM) to the challenged shrimp. Each experiment was conducted in triplicates.

\section{Bacterial Count}

Strains were grown for $24 \mathrm{~h}$ in TS broth to count the colony forming units (CFU). Bacteria were centrifuged at 10,000g during 20min at room temperature and the cellular pellet was washed two times with sterile saline water $(0.85 \%$
$\mathrm{NaCl}$ ) and resuspended in $1 \mathrm{~mL}$ of the same water. The bacterial suspension was then adjusted to an optical density of one in a Thermo Spectronic Genesys 2 Spectrophotometer at $580 \mathrm{~nm}$. To determine the CFU/mL of bacterial suspension, serial dilution method was adopted.

\section{Results and Discussion}

In this study, five species of bacteria were isolated from diseased shrimps of different cultured ponds of L. vannamei in Prakasam district. Andhra Pradesh. The diseased animals showed signs like localized cuticular lesions, red coloration of the body and pleopods, reduced feeding, empty gut. In some cases, red colour animals appeared in the corners of ponds. Similar symptoms were also reported by number of workers (Lightner, 1995; Jayasree et al., 2006; Denis Saulneir et al., 2000). The isolated bacteria were identified on the basis morphological and biochemical characters. The isolated bacteria were identified as Vibrio parahaemolyticus, Vibrio harveyi, Vibrio alginolyticus, Vibrio mimicus and Vibrio vulnificus. Among the five bacterial species $V$. parahaemolyticus and V. harveyi has dominated in all diseased shrimp samples. The morphological and biochemical characters were given in Table-1. All the species of bacteria isolated in the present study are gram native, rod shaped and fermentative bacteria. On agar plates $V$. parahaemolyticus cultures appear as smooth, motile, circular, opaque colonies with entire margins. It showed oxidative positive while catalase negative. While $V$. alginolyticus, V.fluvialis and $V$. mimicus showed oxidative, catalase positive and fermentative bacteria. By virtue of biochemical test the isolated bacteria were identified as V. parahaemolyticus, V. alginolyticus, $V$. fluvialis and $V$. mimicus. The same characters were described by Buchanan and Gibbons (1974). Vibrio species are part of the natural microflora of wild and cultured shrimps (Sinderman, 1990) and become opportunistic pathogens when natural defence mechanisms are suppressed (Brock and Lightner, 1990). They are usually associated with multiple etiological agents. However, some of species of Vibrio have been identified as primary pathogens (Owens and Hall-Mendelin, 1989; Owens et al, 1992; Lavilla-Pitogo et al., 1990; de la Peñaa et al., 1995). Some of the pathogens like $V$. parahaemolyticus, $V$. harveyi, and $V$. vulnificus have causes serious disease problems in Thailand (Nash et al., 1992) and the Philippines (Lavilla-Pitogo et al., 1990). In the present study; it has been observed that same species of Vibrio bacteria have associated with diseased shrimp. Harris (1995) reported that luminescent $V$. harveyi appears to release exotoxins (Liu et al., 1996) and may cause $80-100 \%$ mortality in $P$. monodon hatcheries. Species like V. anguillarum, V. campbelli, V. nereis, $V$. cholerae and $V$. splendidus have also been reported their association with disease outbreaks in shrimp culture systems by various workers in India and abroad (Chen, 1992; Lavilla-Pitoga, 1990; Esteve and Quijada, 1993; Sahul-Hameed et al., 1996). 
Table 1: Biochemical characters of Vibrio spp., isolated from the diseased shrimps

\begin{tabular}{|c|c|c|c|c|c|c|}
\hline \multirow{2}{*}{ S.N. } & \multirow{2}{*}{ Character } & \multicolumn{5}{|c|}{ Response } \\
\hline & & V.parahae & V. harveyi & V. algi & V. mimi & V.vulni \\
\hline 1 & Colour of colony & Green & Green & Yellow & Yellow & Yellow \\
\hline 2 & Shape & $\mathrm{R}$ & $\mathrm{R}$ & $\mathrm{R}$ & $\mathrm{R}$ & $\mathrm{R}$ \\
\hline 3 & Gram's staining test & - & - & - & - & - \\
\hline 4 & Motility & + & + & + & + & + \\
\hline 5 & Catalse & + & + & + & + & + \\
\hline 6 & Oxidase & + & + & + & + & + \\
\hline 7 & Oxidative/Fermentative & $\mathrm{F}$ & $\mathrm{F}$ & $\mathrm{F}$ & $\mathrm{F}$ & $\mathrm{F}$ \\
\hline 8 & Acid production from glucose & + & + & + & + & + \\
\hline \multirow{4}{*}{9} & Nacl tolerance & & & & & \\
\hline & $5 \%$ & + & + & + & + & + \\
\hline & $8 \%$ & + & + & + & + & + \\
\hline & $10 \%$ & + & + & + & + & + \\
\hline \multirow{4}{*}{10} & Decarboxylation of Amino acids & & & & & \\
\hline & Arginine & - & - & - & - & - \\
\hline & Ornithine & + & + & + & + & + \\
\hline & Lysine & - & - & + & + & + \\
\hline 11 & Methyl red test & + & + & + & + & + \\
\hline 12 & VP test & - & - & + & - & - \\
\hline 13 & Indole test & + & + & - & + & + \\
\hline 14 & Starch hydrolysis & - & - & + & + & - \\
\hline 15 & Urase hydrolysis & - & + & + & + & + \\
\hline 16 & Gelatin liquefaction & + & + & - & + & + \\
\hline \multirow[t]{2}{*}{17} & Utilization of carbohydrates & & & & & \\
\hline & L-Arbinose & + & - & + & - & - \\
\hline $\mathrm{a}$ & Dextrose & + & + & + & + & + \\
\hline $\mathrm{b}$ & Fructose & + & + & + & + & + \\
\hline $\mathrm{c}$ & Lactose & + & - & - & - & - \\
\hline d & Mannose & - & - & + & + & - \\
\hline $\mathrm{e}$ & Galactose & + & + & + & + & - \\
\hline$f$ & Sucrose & + & + & + & - & + \\
\hline $\mathrm{g}$ & Trehelose & + & + & - & + & + \\
\hline h & Salicin & + & + & + & + & - \\
\hline $\mathrm{i}$ & Xylose & - & - & - & - & - \\
\hline 18 & Citrate utilization & - & + & + & + & + \\
\hline 19 & Nitrate reduction & - & + & + & + & + \\
\hline
\end{tabular}

-: Negative, +: Positive, R: Rods, F: Fermentative, O: Oxidative, V. parahae: V. parahaemolyticus, V.harveyi, V. alginolyticus, V.mimi: V.mimicus, V.vulni: V.vulnificus 
Table 2: Results of artificial infection trials with Vibrio spp. bacteria isolated from diseased shrimp

\begin{tabular}{|l|l|l|l|l|l|}
\hline S.N. & Bacterial species & Shrimp & Route of injection & Dose & $\begin{array}{l}\text { Symptoms Observed in } \\
\text { challenged shrimp }\end{array}$ \\
\hline 1 & V. parahaemolyticus & L.vannamei & IM & $10^{5} \mathrm{cfu} / \mathrm{shrimp}$ & $\begin{array}{l}\text { Localized lesions and red } \\
\text { colorations of body and pleopods }\end{array}$ \\
\hline 2 & V. harveyi & L.vannamei & $\mathrm{IM}$ & $10^{5} \mathrm{cfu} / \mathrm{shrimp}$ & $\begin{array}{l}\text { Localized lesions and red } \\
\text { colorations of body and pleopods }\end{array}$ \\
\hline 3 & V. alginolyticus & L.vannamei & $\mathrm{IM}$ & $10^{6} \mathrm{cfu} / \mathrm{shrimp}$ & No symptoms \\
\hline 4 & V. mimicus & L.vannamei & $\mathrm{IM}$ & $10^{6} \mathrm{cfu} / \mathrm{shrimp}$ & No symptoms \\
\hline 5 & V. vulnificus & L.vannamei & $\mathrm{IM}$ & $10^{6} \mathrm{cfu} / \mathrm{shrimp}$ & No symptoms \\
\hline
\end{tabular}

IM: intra-muscular; CFU: Colony forming unit

Jayasree et al. (2006) have reported occurrence of five types of diseases in shrimp culture systems, such as tail necrosis, shell disease, red disease, loose shell syndrome (LSS) and white gut disease (WGD) and association of Vibrio spp. in $P$. monodon from culture ponds of coastal Andhra Pradesh. Among these, LSS, WGD, and red disease caused mass mortalities in commercial shrimp culture ponds. They have isolated six species of Vibrio species like $V$. harveyi, $V$. parahaemolyticus, $V$. alginolyticus, $V$. anguillarum, $V$. vulnificus and V. splendidus were isolated from diseased shrimp. Jawahar Abraham (2004) reported the distribution and species composition of luminous bacteria in commercial shrimp hatcheries.

In this study, an experimental infection trial indicates that all the bacteria isolated from diseased shrimps are pathogenic in nature. $V$. parahaemolyticus is highly pathogenic and it produced disease symptoms within $24 \mathrm{~h}$ after injection. While $V$. harveyi is moderately pathogenic to challenged animals. In most cases, a high inoculum was needed to reproduce the disease and to reisolate the inoculated bacteria from the experimentally infected shrimp (Lightner, 1988). However, pathogenic Vibrio isolates have also been detected in apparently healthy shrimp (Nakai et al., 1997; Vandenberghe et al., 1998) and in seawater samples from near-shore and estuary areas, where shrimp farms rearing water is pumped and from affected farms, (Lightner, 1992; Lavilla-Pitogo et al., 1990, 1998; Moriarty, 1998), as well as in sediment (de la Pena et al., 1992). These observations lead researchers to consider Vibrio diseases as secondary infections due to opportunistic pathogens and occurring only in immunologically compromised shrimps. Primary causes could encompass other infectious agents, nutritional deficiencies or intoxication, environmental and management practices and induced stress.

\section{Conclusion}

In the present study, five species of bacterial viz., Vibrio parahaemolyticus, Vibrio harveyi, Vibrio alginolyticus, Vibrio mimicus and Vibrio vulnificus were isolated from Vibriosis affected diseased shrimp. All the species of bacteria were pathogenic in nature. Among the five species of bacteria, Vibrio parahaemolyticus was highly pathogenic in nature while $\mathrm{V}$. harveyi was moderately pathogenic to challenged shrimps.

\section{References}

Alapide-Tendencia EV and Dureza LA (1997) Isolation of Vibrio spp. from Penaeus monodon Fabricius, with red disease syndrome. Aquaculture 154: 107-114. DOI: 10.1016/S0044-8486(97)00045-8

Anderson IG, Shamsudin MN and Shariff M (1988) Bacterial septicemia in juvenile tiger shrimp, Penaeus monodon, cultured in Malaysian brackish water ponds. Asian Fish Sci. 2: 93-108.

Baticados MCL, Lavilla-Pitogo CR, Cruz-Lacierda ER, de la Pena LD and Sunaz NA (1990) Studies on the chemical control of luminous bacteria Vibrio harveyi and $V$ splendidus isolated from diseased Penaeus monodon larvae and rearing water. Dis. Aquat. Org. 9: 133-139. DOI: $10.3354 /$ dao009133

Brock JA and Lightner DV (1990) Diseases of Crustacea, In: O. Kinne (ed.) Diseases of Marine Animals Vol. 3, Biologische Anstalt Helgoland, pp. 245-424

Buchanan RE and Gibbons NE (1974) Bergey' s Manual of Determinative Bacteriology, 8th Eds. Baltimore and Williams Publication

Chen D (1992) An overview of the disease situation, diagnostic techniques, treatments and preventatives used on shrimp farms in China. In: Fuls W and Main KL (eds.) Diseases of Cultured Penaeid Shrimp in Asia and the United States, The Oceanic Institute, Hawaii. pp. 47-55.

Chen FR, Liu PC and Lee KK (2000) Lethal attribute of serine protease secreted by Vibrio alginolyticus strains in Kurama Prawn Penaeus japonicas, Zool. Naturforsch. 55: 94-99.

Cook DW and Lofton SR (1973) Chitinoclastic bacteria associated with shell disease in Penaeus shrimp and the blue crab. $J$. Wild Dis. 9: 154-159. DOI: 10.7589/0090-3558-9.2.154

Costa R, Mermoud I, Koblavi S, Morlet B, Haffner P, Berthe F, Legroumellec M and Grimont P (1998) Isolation and characterization of bacteria associated with a Penaeus stylirostris disease Syndrome. In New Caledonia. 
Aquaculture 164: 297-309. DOI: 10.1016/S00448486(98)00195-1

de la Pena LD, Tamaki T, Momoyama K, Nakai T and Muroga K (1992) Detection of the causative bacterium of vibriosis in Kuruma prawn, Penaeus japonica. Gyobyo Kenkyu. 27(4): 223-228. DOI: $10.3147 /$ jsfp.27.223

Denis Saulnier, Phillipe Haffner, Cyrille Goarant, Peva Levy, Dominique Ansquer (2000) Experimental infection models for shrimp Vibriosis studies: a review. Aquaculture 191: 133-144. DOI: 10.1016/S00448486(00)00423-3

Esteve M and Quijada R (1993) Evaluation of three experimental infection techniques with Vibrio anguillarum in Penaeus brasiliensis in Carillo et al., (ed.), From discovery to commercialization, World Aquaculture, European Aquaculture Society Special publication 19 Torremolinos, Spain p 129.

Harris L (1995) The involvement of toxins in the virulence of Vibrio harveyi strains pathogenic to the black tiger shrimp Penaeus monodon and the use of commercial probiotics to reduce shrimp hatchery disease outbreaks caused by $V$. harveyi strains, CRC for Aquaculture, Scientific Conference abstract, Bribie Island, Australia.

Jawahar Abraham T and R Palaniappan (2004) Distribution of luminous bacteria in semi-intensive penaeid shrimp hatcheries of Tamil Nadu, India. Aquaculture 232(1-4): 81-90. DOI: 10.1016/S0044-8486(03)00485-X

Jayasree L, Janakiram P and Madhavi R (2006) Characterization of Vibrio spp. Associated with diseased shrimp from culture ponds of Andhra Pradesh (India). Journal of the World Aquaculture Society 37(4): 523. DOI: 10.1111/j.1749-7345.2006.00066.x

Jiravanichpaisal P and Miyazaki T (1994) Histopathology, biochemistry and pathogenicity of Vibrioharveyi infecting black tiger shrimp Penaeus monodon. J. Aquat. An. Health 6: 27-35. DOI: $10.1577 / 1548-$ 8667(1994)006<0027:HBAPOV>2.3.CO;2

Karunasagar I, Pai R, Malathi GR and Karunasagar I (1994) Mass mortality of Penaeus monodon larvae due to antibiotic resistant Vibrio harÍeyi infection. Aquaculture 128: 203209. DOI: 10.1016/0044-8486(94)90309-3

Lavilla-Pitogo CR, Leano EM and Paner MG (1998) Mortalities of pond-cultured juvenile shrimp, Penaeus monodon, associated with dominance of luminescent Vibrios in the rearing environment. Aquaculture 164: 337-349. DOI: 10.1016/S0044-8486(98)00198-7

Lavilla-Pitogo CR, Baticados MCL, Cruz-Lacierda ER and de la Pena LD (1990) Occurrence of luminous bacterial disease of Penaeus monodon larvae in the Philippines. Aquaculture 91: 1-13. DOI: 10.1016/00448486(90)90173-K

Lightner DV (1992) Shrimp pathology: major diseases of concern to the farming industry in the Americas. Mem. Congr. Ecuat. Aquacult, 177-195.
Lightner DV (1988) Vibrio disease of Penaeid shrimp, In: Sindermann CJ, Lightner DV, Eds.., Disease Diagnosis and Control in North American Marine Aquaculture Developments in Aquaculture and Fisheries Science vol. 17 Elsevier, Amsterdam, pp. 42-47.

Liu PC, Lee KK and Chen SN (1996) Pathogenicity of different isolates of Vibrio harveyi in tiger shrimp, Penaeus monodon. Letters in Applied Microbiology 22: 413-416. DOI: 10.1111/j.1472-765X.1996.tb01192.x

Lovett DL and Felder DL (1990) Ontogenetic changes in enzyme distribution and mid-gut function in developmental stages of Penaeus setiferus (Crustacea, Decapoda, Penaeidae). Biol Bull (Woods Hole) 178: 164-174

Moriarty DW (1998) Control of luminous Vibrio species in penaeid aquaculture ponds. Aquaculture 164: 351-358. DOI: 10.1016/S0044-8486(98)00199-9

Nakai T, Nishimura Y and Muroga K (1997) Detection of Vibrio penaeicida from apparently healthy Kuruma prawns by RT-PCR, Bull. Eur. Ass. Fish Pathol, 173(4): 131-133.

Nash G, Nithimathachoke C, Tungmandi C, Arkarjamorn A, Prathanpipat P and Ruamthaveesub P (1992) Vibriosis and its control in pond-reared Penaeus monodon in Thailand. In: Shariff M, Subasinghe RP and Authur JR (eds.) Diseases in Asian Aquaculture 1. Fish Health Section, Asian Fisheries Society, Manila, Philippines, pp. 143-155

Owens L and Hall-Mendelin (1989) Recent Advances in Australian shrimps (sic) diseases and pathology. Advances in Tropical Aquaculture, Tahiti, Aquacop, IFMER, Actes de Colloque 9: 103-112.

Owens L, Muir P, Sutton D and Wingfield M (1992) The pathology of microbial diseases in tropical Australian Crustacea. In: M. Shariff, RP Subasinghe and JR Authur (eds.) Diseases in Asian Aquaculture, Fish Health Section, Asian Fisheries Society, Manila, Philippines, pp. 165-172.

Pizzutto M and Hirst RG (1995) Classification of isolates of Vibrio harveyi virulent to Penaeus monodon larvae by protein profile analysis and M13 DNA fingerprinting. Dis. Aquat. Org. 21: 61-68. DOI: 10.3354/dao021061

Robertson PAW, Calderon J, Carrera L, Stark JR, Zherdmant M and Austin B (1998) Experimental Vibrio haríleyi infections in Penaeus vannamei larvae. Dis. Aquat. Org. 32: 151-155. DOI: $10.3354 /$ dao032151

Ruby EG, Greenberg EP and Hastings JW (1980) Planktonic marine luminous bacteria: species distribution in the water column. Applied and Environmental Microbiology 39: 302-306.

Sahul Hameed AS, Rao PV, Farmer JJ, Hickman-Brenner W and Fanning GR (1996) Characteristics and pathogenicity of a Vibrio cambelli-like bacterium affecting hatchery-reared Penaeus indicus (Milne Edwards, 1837), larvae. Aquacult, Res. 27: 853-863. DOI: 10.1111/j.13652109.1996.tb01245.x

Sindermann CJ (990) Principal Diseases of Marine Fish and Shellfish, 2nd edition, Academic Press, New York 
Song YL and Lee SP (1993) Characterization and ecological implication of luminous Vibrio haríeyi isolated from tiger shrimp Penaeus monodon, Bull. Inst. Zool., Acad. Sin. 32: 217-220.

Sunaryanto A and Mariam A (1986) Occurrence of pathogenic bacteria causing luminescence in penaeid larvae in Indonesia hatcheries. Bull. Br. Aqua. Dev. Center 8: 6470.
Taylor HH and Taylor EW (1992) Gills and lungs: the exchange of gases and ions. In: Harrison FW, Humes AG (eds.) Microscopic anatomy of invertebrates 10. Wiley-Liss, New York, p 203-293

Vandenberghe J, Li Y, Verdonck L, Li J, Sorgeloos P, Xu HS, Swings J (1998) Vibrio associated with Penaeus chinensis, Crustacea: Decapoda larvae in Chinese shrimp hatcheries. Aquaculture 169: 121-132. DOI: 10.1016/S00448486(98)00319-6 